Available online at JSJ: Jurnal Studi Jurnalistik

http://journal.uinjkt.ac.id/index.php/jsj

JSJ: Jurnal Studi Jurnalistik, 2 (2), 2020, 168-185

\title{
Konstruksi Media Online Mengenai Pemberitaan Blame Game Terkait Asal Mula Munculnya Virus Corona Analisis Framing Pada Newyorktimes.Com Dan Xinhua.Com
}

\author{
Muhammad Yudistira Meydianto \\ Ahmad Toni \\ Program Pascasarjana Ilmu Komunikasi \\ Universitas Budi Luhur \\ Muhammadyudistira165@gmail.com \\ Ahmad.toni@budiluhur.ac.id
}

\begin{abstract}
Abstrak
Penelitian ini dilatari adanya saling tuduh antara dua media mengenai asal mula Covid-19. New York Times (Amerika Serikat) menuduh Covid-19 berasal dari China, sedangkan Xinhua (China) menuduh sebaliknya. Bagaimana New York Times dan Xinhua.com menkonstruksi pemberitaan mengenai asal Covid-19? Penelitian ini menggunakan analisis framing Robert N. Entman, yang mengatakan bahwa framing dapat dilihat dari dua dimensi besar, yaitu: "Seleksi isu dan penonjolan aspek". Hasil penelitian ini menunjukan bahwa China menolak tuduhan Trump yang menuduh Covid-19 itu sengaja diciptakan dan berasal dari sana. New York Times mendukung pernyataan Trump, namun media ini menyalahkan Trump karena menyebarkan Covid-19 di Amerika Serikat akibat lambannya penanganan.

Kata kunci: framing, seleksi isu, penonjolan aspek
\end{abstract}

Permalink/DOI: http://doi.org/10.15408/jsj.v2i2.16322

\section{Pendahuluan}

Media massa merupakan medium penyebarluasan informasi. J.B Wahyudi (1991) dalam Pengantar Komunikasi Massa (2010:8) mengatakan bahwa media massa adalah sarana untuk menyampaikan isi pesan, pernyataan, informasi yang bersifat umum, kepada sejumlah orang yang jumlahnya relatif besar, tinggalnya tersebar, heterogen, anonim, dan tidak terlembagakan.

Terdapat banyak jenis media massa seperti media televisi, radio dan media cetak, namun hari demi hari teknologi komunikasi semakin berkembang sehingga belakangan telah lahirlah new media, yang 
awal kemunculannya lahir sekitar akhir dari abad ke 20an. Beberapa contoh produk new media adalah internet, website, game online termasuk media online.

Media online menjadi bukti bahwa media massa telah mengalami revolusi. Selain keunggulannya yang cepat meluas dalam mempublikasikan informasi, media online juga dapat diakses di manapun, khususnya melalui ponsel pintar atau smartphone. Sehingga tidak mengherankan jika para khalayak beralih platform dalam mendapatkan informasi, yakni dari media cetak ke media online dalam hal mendapatkan berita. Hasil riset lembaga riset global GFK dan Indonesian Digital Association (IDA) menunjukkan bahwa konsumsi berita melalui media online paling tinggi dibanding konsumsi berita melalui media lain.

Berdasar riset di lima kota besar Indonesia sepanjang tahun 2015, persentase konsumsi berita melalui online mencapai 96 persen. Angka tertinggi dibandingkan dengan konsumsi berita melalui televisi sebesar 91 persen, surat kabar 31 persen dan radio sebesar 15 persen. Waktu yang menjadi pilihan favorit konsumsi berita adalah pada pukul 12.0015.00 WIB pada hari Senin hingga Jumat. Sedangkan pada hari Sabtu puncak konsumsi berita adalah pada pukul 12.0018.00 WIB. Pada hari Minggu, puncak konsumsi berita berada pada rentan waktu yang lebih panjang, yaitu antara pukul 12.00 hingga pukul 21.00 WIB "(https://economy.okezone.com/read/20 16/03/16/320/1337230/96-masyarakatindonesia-konsumsi-berita-online diakses 19/03/ 2020,20:42 WIB).

Media online yang sudah menjadi primadona tetap saja membutuhkan pemasukan, sehingga media online masih harus bergantung pada jumlah pembaca atau "klik". Kedua hal tersebut akan berpengaruh terhadap jumlah iklan yang masuk guna memenuhi kebutuhan produksi di dapur redaksi. Media juga saling berlomba dan adu cepat menyajikan berita. Untuk mendapatkan klik dan view yang banyak yang nantinya akan mempengaruhi pendapatan mereka, media online akhirnya membuat kalimat yang bertujuan memancing rasa ingin tahu masyarakat pada judul berita. Bahkan sebagian media online membuat judul berita yang tidak selaras dengan isinya.

Sedikit disayangkan, media online merupakan media tercepat namun tak jarang kembali dipertanyakan mengenai akurasi beritanya. Begitu juga ketika media online menurunkan berita virus covid-19.

Perdebatan mengenai awal munculnya virus Covid-19 menjadi perdebatan di kalangan media internasional. Awalnya diberitakan bahwa virus ini berasal dari salah satu kota di negara Tionkok yakni kota Wuhan. Dikutip 
dari Center for Disease Control and Prevention, cdc.gov, virus corona merupakan jenis virus yang diidentifikasi sebagai penyebab penyakit pada saluran pernapasan, yang pertama kali terdeteksi muncul di Kota Wuhan, Tiongkok. Virus ini diketahui pertama kali muncul di pasar hewan dan makanan laut di Kota Wuhan. Kemudian dilaporkan bahwa banyak pasien yang menderita virus ini dan ternyata terkait dengan pasar hewan dan makanan laut tersebut. Orang pertama yang jatuh sakit akibat virus ini juga diketahui merupakan para pedagang di pasar itu

(https://bali.idntimes.com/health/medical /denny-adhietya/asal-muasal-danperjalanan-virus-corona-dari-wuhan-keseluruh-dunia-regional-bali/full diakses 20/03/2020, 21:50 WIB).

Peneliti memilih dua portal berita asing dalam melakukan penelitian ini, yakni New York Times media yang berasal dari Amerika Serikat dan Xinhua.com yang merupakan media berasal dari China. Peneliti memilih New York times sebagai media yang berlawanan dengan media China, karena media tersebut cukup gencar membangun berita yang mengatakan negara Republik Rakyat China merupakan tempat virus ini berasal. Pemerintah China juga dinilai tidak sigap dalam mengatasi virus ini dan China sengaja melakukan hal ini sebagai sebuah senjata biologis. Hal ini wajar kerena hingga saat ini Amerika merupakan negara yang paling terdampak dengan virus ini. Per tanggal 21 April 2020, sudah sebanyak 792.759 warga Amerika positif terpapar virus ini, selain itu jumlah kematian di di negara adidaya tersebut juga terbanyak di dunia yakni 42.514 (https://style.tribunnews.com/amp/2020 /04/21/update-corona-dunia-21-april2020-kematian-di-as-tembus-40-ribujerman-terbanyak-pasien-sembuh?page=2 Diakses 21 April 2020 pukul 19:50).

Sementara media-media China menepis anggapan media Amerika tersebut. Media China justru berbalik menuduh bahwa para tentara Amerika lah yang sengaja menyebarkan Virus Corona di wiliyahnya khususnya di Kota Wuhan. China mengeluarkan pernyataan tersebut bukan tanpa alasan, karena pada bulan Oktober 2019 terdapat pertandingan dunia militer di kota Wuhan. Kemudian banyak yang berasumsi adanya peristiwa ini dikaitkan dengan persaingan perang dagang kedua negara tersebut.

\section{Landasan Teori Dan Konsep}

\subsection{Teori Kontruksi Realitas Sosial}

Teori kontruksi realitas sosial pertama kali diperkenalkan oleh Peter Berger bersama Thomas Luckman dalam bukunya yang berjudul The Social Contruction of Reality. Peter Beter dan Thomas Luckman menyatakan bahwa 
pengertian dan pemaknaan terhadap sesuatu muncul akbiat adanya komunikasi dengan orang lain. Bahkan didalamnya terdapat realitas sosial yang tidak lebih sekedar dari kontruksi sosial dalam komunikasi tertentu. Artinya dalam kajian ini realitas yang sesungguhnya mengenai kontruksi realitas dan media masa dalam kaitannya dengan pemberitaan (Berger, 1996:12)

Pendekatan kontruksi realitas sosial menurut Peter L Beger dan Luckman terjadi secara simulatan melalui tiga proses sosial, yaitu ekternalisasi, objektivitas dan internalisasi. Pertama, tahap eksernalisasi (penyesuaian diri) merupakan usaha pencurahan atau ekpresi diri manusia ke dalam dunia, baik dalam kegiatan fisik maupun mental. Dalam proses ini dibentuk ekspresi diri untuk menguatkan eksitensi individu dalam masyarakat. Pada tahap eksternalisasi inilah masyarakat dilihat sebagai produk manusia (society is a human product). Kedua objektivitas, merupakan hasil dari eksternalisasi yang telah dicapai manusia baik mental maupun fisik. Hasil ini berupa realitas objektif yang hadir dalam wujud nyata. Ketiga internalisasi, merupakan penyerapan kembali dunia objektif ke dalam kesadaran demikian rupa, sehingga subjektifitas individu dipengaruhi oleh struktur dunai sosial. Berdasarkan ketiga proses ekternalisasi, objektivitas dan internalisasi inilah yang akan terus menerus pada diri individu dalam rangka pemahaman tentang ralitas sosial.

\subsection{Konstruksi Realitas Media Massa}

Konstruksi realitas media tentunya akan menghasilkan realitas media yang tentunya berbeda-beda. Tergantung bagaimana kepentingan media itu sendiri. Pandangan konstruksionis mempunyai posisi yang berbeda dibandingkan positivis dalam menilai media. Dalam pandangan positivis, media dilihat sabagai saluran. Dalam pandangan konstruksionis, media dilihat sebaliknya. Media bukanlah sekedar saluran yang bebas, ia juga subjek yang mengkontruksi realitas, lengkap dengan pandangan, bias, dan pemihakkannya (Eriyanto,2011:25).

Berdasarkan teori realitas diatas, peneliti bisa menarik kesimpulan bahwa media selalu mengkonstruksi realitas dengan bahasa sebagai dasarnya. Media merupakan alat konstruksi sosial yang memberikan realitas sesuai dengan kepentingannya masing-masing dengan tujuan untuk menarik perhatian dan mempengaruhi masyarakat. Dalam pemberitaan mengenai pemberitaan asal muasal virus corona berasal yang terjadi di berita tersebut media telah mengkonstruksi realitas peristiwa yang terjadi secara berbeda-beda, sesuai dengan kepentingan medianya masing-masing. 


\subsection{Teori Computer Mediated Communication (CMC)}

Computer Mediated

Communication (CMC) merupakan proses komunikasi lewat media komputer. Proses komunikasi ini melibatkan orang yang terlibat dalam proses untuk membentuk media untuk berbagai tujuan. CMC juga didefinisikan sebagai proses komunikasi yang terjadi antara manusia melalui perantara komputer yang berbeda. Hal ini dimaksudkan bukanlah bagaimana dua mesin atau lebih dapat berinteraksi, namun bagaimana dua orang atau lebih dapat berkomunikasi antara satu dengan lainnya menggunakan alat bantu komputer melalui program aplikasi pada komputer tersebut (Thurlow, 2005:15). Menurut penelitian Lindlof dan Schatzer (1998) mengatakan bahwa CMC berbeda dengan penggunaan media lain karena sifatnya sementara, multimodal, dengan sedikit penggunaan kode perilaku pengaturan, dan memungkinkan 'manipulasi konten oleh pengguna akhir' pada tingkat tinggi. Meskipun benar bahwa komputer menghubungkan seseorang dengan yang lain, namun pada tahap penggunaannya melibatkan perilaku soliter, pilihan dan respons individualistis, dan anonimitas yang jamak (Baym, 2002). Maka dapat dikatakan bahwa hubungan yang tercipta atau termediasikan oleh mesin-mesin komunikasi baru seringkali bersifat sementara, dangkal, dan tanpa komitmen (McQuail, 2011).

\section{Metode Penelitian}

Peneliti menggunakan metode analisis teks dengan pendekatan analisis framing yang dikemukakan oleh Robert $\mathrm{N}$. Entman. Entman mengatakan bahwa framing adalah pendekatan untuk mengetahui bagaimana perspektif atau cara pandang yang digunakan oleh wartawan ketika menyeleksi isu dan menulis berita. (Eriyanto, 2011:221).

Robert N Entman membagi dua dimensi pembingkaian yakni, seleksi isu dan penonjolan aspek. Seleksi isu merupakan Aspek yang berhubungan dengan pemilihan fakta. Dari realitas kompleks dan beragam itu, aspek mana yang diseleksi untuk ditampilkan? Dari proses ini selalu terkandung di dalamnya ada bagian berita yang dimasukan (included), tetapi ada juga berita yang dikeluarkan (excluded). Tidak semua aspek atau bagian dari isu ditampilkan, wartawan memilih aspek tertentu dari suatu isu. Penonjolan Aspek merupakan Aspek yang berhubungan dengan penulisan fakta. Ketika aspek tertentu dari suatu peristiwa/isu tersebut dipilih, bagaimana aspek tersebut ditulis? Hal ini sangat berkaitan dengan pemakaian kata, kalimat, gambar, dan citra tertentu untuk ditampilkan kepada khalayak. 
Berdasarkan konsep Entman, framing pada dasarnya merujuk pada pemberitaan definisi, penjelasan, evaluasi, dan rekomendasi dalam suatu wacana untuk menekankan kerangka berpikir tertentu terhadap suatu peristiwa yang diwacanakan. (Eriyanto, 2011:222).

Terdapat empat elemen framing versi Robert N Entman, yakni; (a). Define Problems (Pendefinisan masalah), Bagaimana suatu peristiwa/ isu dilihat? Sebagai apa? Atau sebagai masalah apa?; (b). Diagnose causes (Memperkirakan masalah atau sumber masalah), Peristiwa itu dilihat disebabkan oleh apa? Apa yang dianggap sebagai penyebab dari suatu masalah? Siapa (aktor) yang dianggap sebagai penyebab masalah?; (c). Make moral judgement (Membuat keputusan moral) Nilai moral apa yang disajikan untuk menjelaskan masalah? Nilai moral apa yang dipakai untuk melegatimasi atau mendelegimitasi suatu tindakan?; (d). Treatment Recommendation (Menekankan penyelesaian), Penyelesaian apa yang ditawarkan untuk mengatasi masalah/isu? Jalan apa yang ditawarkan dan harus ditempuh untuk mengatasi masalah? (Eriyanto, 2011:223-234).

Define Problems (Pendefinisan masalah) adalah elemen pertama yang dapat dilihat mengenai framing, elemen ini merupakan master frame atau bingkai yang paling utama dan menekankan bagaimana peristiwa dipahami oleh wartawan. Diagnose causes (memperkirakan penyebab masalah) merupakan elemen framing untuk membingkai siapa yang dianggap sebagai aktor dari suatu peristiwa, penyebab disini bisa berarti apa (what), tetapi bisa juga siapa (who). Make moral judgment (membuat keputusan moral) adalah elemen framing yang dipakai untuk membenarkan atau memberi argumentasi pada pendefinisian masalah yang sudah dibuat. Treatment recommendation (menekankan penyelesaian), elemen ini dipakai untuk menilai apa yang dikehendaki oleh wartawan, jalan apa yang dipilih untuk menyelesaikan masalah, dan penyelesaian. itu tergantung kepada bagaimana peristiwa itu dilihat dan siapa yang dipandang sebagai penyebab masalah (Eriyanto, 2011:225-227).

Tujuan dari penelitian ini adalah untuk menganalisis dan mengungkapkan maksud dari media asing yang berseteru dengan cara saling tuduh dan mengelak bahwa virus corona bukan berasal dari negara mereka malainkan dari negara asal media yang berseberangan tersebut.Ditengahproses mengumpulkan, mengungkapkan serta menjelaskan berbagai masalah serta tujuan dari penrlitian ini, Penelitian ini menggunakan pendekatan analisis framing versi Robert N. Entman. 
Peneliti mendapakan dua jenis sumber data, yaitu data primer dan sekunder. Peneliti mengumpulkan data primer yang diperoleh dari naskah berita yang dimuat oleh situs New York Times dan Xinhua.com, Peneliti telah melakukan observasi pada objek penelitian yakni teks berita yang berkaitan dengan tuduhan dan sangkalah pemberitaan mengenai asal dari virus corona itu berasal. Peneliti melakukan pengumpulan data sekunder dengan cara mencari sumber referensi melalui sumber bacaan, kegiatan studi kepustakaan, jurnal ilmiah, skripsi terdahulu, browsing melalui media internet, dan beberapa contoh laporan tugas akhir sehingga peneliti mendapatkan infomasi atau data yang lengkap untuk penelitian ini.

Dalam metode analisis data, Peneliti menggunakan pendekatan analisis deskriptif, Peneliti akan menggambarkan temuan-temuan yang didapat, baik data gambar ataupun kalimat-kalimat pada objek penelitian. Dalam penelitian ini, peneliti akan mendeskripsikan teks berita mengenai pemberitaan virus corona di media New York Times dan Xinhua.com.

\section{Hasil Penelitian dan Pembahasan}

Pada sub bab ini akan menjelaskan hasil enelitian dan pembahasan terkait dengan blame game mengenai awal mula virus corona berasal. Setiap media memiliki pandangan masing masing dalam membangun sebuah berita, dalam penelitian ini, Penekiti berniat menjelaskan analisis framing tentang pemberitaan Blame game yang dilakukan oleh oleh media China dan Amerika terkait awal kemunculan virus corona pada media online Xinhua.com dan New York Times dengan menggunakan analisis framing Robert N. Entman.

Berdasarkan empat dimensi diatas, Peneliti akan memberikan analisis sesuai dengan empat dimensi tersebut, setelah peneliti melakukan analisis, langkah berikutnya peneliti akan meninterpretasikan sehingga nantinya diharapkan akan diketahui bagaimana New York Times dan Xinhua.com dalam membingkai informasi yang diberitakan menggunakan model analisis ini.

1. Struktur Berita Xinhua.com

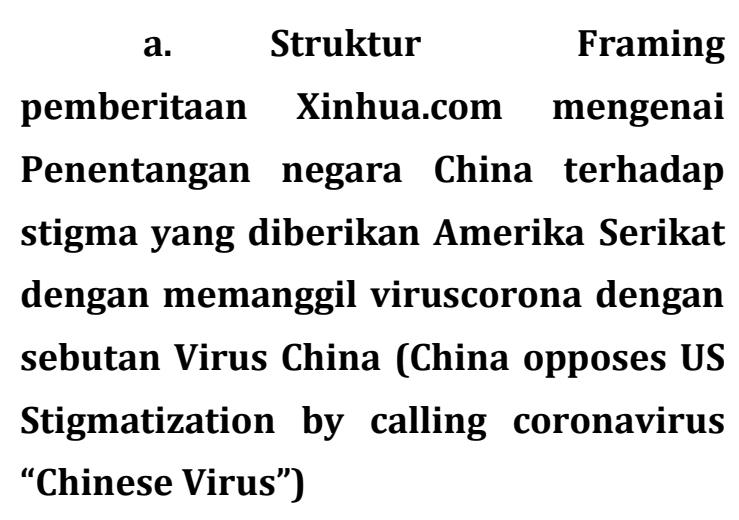

Define Problems: (Pendefinisian Masalah) 
Pendefinisian masalah ini terkait dengan berita penolakan stigma yang diberikan oleh Amerika Serikat kepada China dengan mengganti nama Virus Corona menjadi Virus China yang dimuat di Xinhua.com. Peneliti mencari pendefinisian masalah ini dari dari berita terpilih, berikut adalah pendefinisian masalah dari berita terkait:

"China is strongly indignant at and firmly opposes U.S. stigmatization by calling the novel coronavirus "Chinese virus"

Berdasarkan dari kutipan diatas, jelas bahwa Xinhua.com ingin menyatakan bahwa China sangat marah dan menentang stigma Amerika Serikat yang menyatakan bahwa nama virus corona diganti dengan nama virus China dan meminta Amerika Serikat untuk berhenti menyatakan hal demikian dikarenakan tuduhan tersebut tidak memiliki dasar untuk menyebut bawasannya virus corona berasal dar wilayah Republik Rakyat China.

\section{Diagnose Causes: (Memperkirakan Masalah)}

Donal Trump, yakni Presiden Amerika Serikat sekaligus orang yang mengganti sebutan virus corona dengan sebutan Virus China merupakan sumber masalah karena menurut pihak China tuduhannya tidak memiliki dasar.

"Spokesperson Geng Shuang made the remarks at a press conference when asked to comment on U.S. President Donald Trump's tweet Monday, in which he called the novel coronavirus "Chinese virus, Recently, some U.S. politicians have connected the novel coronavirus with China, aiming to stigmatize China," Geng said. "We are strongly indignant at and firmly oppose that."

Didalam peristiwa ini Donal Trump untuk sekian kalinya menyalahkan China karena menyebarnya virus corona secara menglobal, puncaknya Trump menyebut covid19 adalah berasal dari negara yang ada di Asia tersebut.

\section{Make Moral Judgment (Membuat Keputusan Moral)}

Masalah moral pada berita ini adalah ketika pihak China melalui kementerian Negrinya meminta agar Amerika dapat memperbaiki kesalahannya dan berhenti membuat Tuduhan yang tidak ada dasarnya.

"urges the United States to correct its mistakes and stop making groundless accusations against China, according to a Chinese Foreign Ministry spokesperson"

Badan Organisasi Kesehatan Dunia juga melarang untuk membangun stigma dengan mengaitkan virus dengan negara dan wilayah tertentu.

"The World Health Organization and the international community clearly and definitely opposed to stigmatization by 
associating the virus with specific countries and regions."

Berdasarkan penjelasan diatas, Xinhua.com inigin menyampaikan dan mempertegas bahwa pihak republic Rakyat China menolak kerasa jika dikaitkan bawasannya Covid19 bukanlah sebuah virus yang berasal dari negaranya, ditambah dengan statment yang diberikan oleh badan organisasi kesehatan Internasional yang melarang untuk mengkaitkan virus dengan negra dan wiyah tertentu.

Treatment

Recomendation

(Menekankan Penyelesaian

Mentri luar negeri China meminta agar pihak Amerika Serikat pada saat ini fokus kepada negaranya sendiri terlebih dahulu

"What the United States should do first is to manage its own business well, and play a constructive role in international cooperation on pandemic fight and safeguarding global public health security, Geng said"

Pihak China menyarankan agar Amerika Serikat sekarang fokus pada mengelola bisnisnya sendiri dengan baik dan memainkan perannya sebagai negara superpower dalam bekerja sama dengan negara-negara lainnya dalam memerangi pandemi ini dan menjaga kesehatan masyarakat global. b. Struktur Framing pemberitaan Xinhua.com mengenai lembaga Jerman yang meragukan tuduhan Amerika Serikat mengenai labolaturium di China yang diduga sebagai tempat dimana China menciptakan virus corona (German agency doubts U.S. coronavirus allegations against Chinese lab)

Define Problems: Melalui pemberitaan ini, Xinhua yang merupakan media pemberitaan pemerintah seperti ingin meyakinkan bawasannya virus corona bukan dari negara, kali ini Xinhua mengeluarkan berita bawasannya sebuah Lembaga di Jerman meragukan bawasaanya virus corona sengaja diciptakan di laboraturin di China

"WASHINGTON, (Xinhua) -Germany's federal intelligence agency doubts U.S. allegations that COVID-19 "originated in a Chinese laboratory", saying the allegations were aimed at diverting attention from U.S. failure to contain the disease, U.S. television network CNBC said, citing a German magazine"(German Agency Doubs U.S Coronavirus Allegations Againts Chinese Lab)

Lembaga Jerman tersebut mengatakan bahwa tuduhan Amerika Serikat ini sebagai sebuah alibi mereka karena gagal mengatasi virus ini sehingga korban banyak berjatuhan di Amerika Serikat. 
Diagnose Cause: Hal yang menjadi masalah disini adalah tuduhan Amerika Serikat beserta aliansinya tidak valid karena tidak ada bukti yang mendukung dari tuduhan yang dilontarkan tersebut.

"The German Federal Intelligence Service (BND) had asked members of the U.S.-led "Five Eyes" intelligence alliance for evidence to support the allegations, but none of the five wanted to back the allegations stemming from U.S. Secretary of State Mike Pompeo, CNBC said in an article on its website."

Lembaga Jerman tersebut meminta bukti dukungan yang dapat meyakinkan bawasannya virus corona sengaja diciptkan oleh pihak China.

Make Moral Judgment: Lembaga Jerman tersebut memandang bahwa Amerika hanya mengalihkan perhatian public agar tidak dipandang bahwa pemerintah Amerika Serikat gagal dalam menanggulangi pandemic ini.

"In a report prepared for German Defence Minister Annegret KrampKarrenbauer, BND concluded that the U.S. allegations "were a deliberate attempt to divert public attention from U.S. President Donald Trump's 'own failures'", according to CNBC."

\section{Treatment Recommendation:}

Pada pemberitaan disini tidak ada Treatment Recommendation yang diberika secara detail selain hanya meminta bukti bawasaanya tuduhan yang diberika Amerika dan Aliansinya memiliki dasar dan hal yang mendukung kecuali mereka mampu memberikan bukti valid dan bisa dipertanggungjawabkan.

c. Struktur Framing pemberitaan Xinhua.com mengenai Politisasi Corona Virus ditengah Pertarungannya, hanya membuang waktu (Spotlight: Politicizing coronavirus waste of time in pandemic battle)

Define Problems: Melalui pemberitaan ini, Pihak China menegaskan untuk menolak tuduhan Trump yang menurutnya virus corona sengaja diciptakan oleh China sendiri di laboratorium di pusat kota Wuhan.

"NOT MANMADE VIRUS, Many researchers have ruled out that the virus was created, or engineered in a lab, with genetic studies showing that the virus has a natural source, evolution, and a transmission most probably of leaping from animal to human."

Diagnose Cause: Trump dan kawan-kawanlah yang lagi lagi menjadi sumber masalah, karena menuduh bahwa China sengaja menciptakan virus corona yang dinilai sebagai sebuah konspirasi

"Mr. Trump's aides and Republicans in Congress have sought to blame China for the pandemic in part to deflect criticism of the administration's mismanagement of the 
crisis in the United States, which now has more coronavirus cases than any country,"

Make Moral Judgment: Amerika Serika, sebuah negara super power tentu tidak ingin dicap gagal dalam menangani pandemi ini serta dicap gagal dalam melindungi warga negaranya, alih alih serius dalam menangani pandemi ini, justru pihak Amerika menyalahkan pihak lain

"However, instead of focusing efforts on saving lives and livelihoods, politicians in some countries, especially in the United States, have tried to conveniently scapegoat China for their own failures to tackle the coronavirus outbreak."

\section{Treatment Recommendation:}

Dalam memberikan pemecahan masalah atau jalan tengah mengenai adanya blame game ini,, Richard Horton, pemimpin redaksi jurnal medis terkemuka mendesak bawasannya baik pihak Amerika dan China harus menyingkirkan egonya masing masing yakni saling menyalahkan dengan adanya pandemi ini

"We should be working together to face down this threat," he said, adding that it is useless and wrong to blame China for the origin of the novel coronavirus. In a signed letter recently published by The New York Times, more than 70 U.S. and Chinese public health scholars urged the United States and China to cooperate in tackling COVID-19. Officials in Washington,
Beijing and beyond should stride cautiously, however. Avoid infusing the politics needed to quell COVID-19 with tactics designed to serve partisan interests," read the letter."

\section{Struktur Berita New York} Times.com

a. Struktur Framing pemberitaan newyorktimes.com mengenai pemberitaan yang dikeluarkan oleh China bahwa mereka menuduh balik bahwa pihak Amerika membawa corona virus melalui Tentaranya yang datang ke China (China Spins Tale That the U.S. Army Started the Coronavirus Epidemic).

Define Problems: Isu ini dilihat sebagai sebuah respon China terhadap tuduhan Donal trump kepada pihak China, China telah menolak stigma bawasannya virus Corona bersumber dari negaranya, kini China Berbalik menuduh pihak Amerikalah yang sengaja membawa virus Corona ke China, China menganggap virus ini dibawa oleh tentaranya pada kunjungannya ke China bulan Oktober 2019 silam.

"China is pushing a new theory about the origins of the coronavirus: It is an American disease that might have been introduced by members of the United States Army who visited Wuhan in October." 
China menganggap tentara Amerika membawa virus corona ke wuhan ketika ada perlombaan militer di China dan pada saat itu tentara Amerika Serikat ikut berpartisipasi dalam perlombaan militer internasional. Pentagon mengirim 17 tim dengan lebih dari 280 atlet dan anggota staf lainnya ke acara tersebut, jauh sebelum ada wabah yang dilaporkan.

Namun tidak serta merta Amerika menerima tuduhan China tersebut, China kembali menyalahkan Amerika karena dianggap gagal menangani virus ini pada awal kemunculanya, Virus ini muncul di Kota Wuhan, disanalah semua bermula ketika ada seseorang sudah terinfeksi sehingga akhirnya menyebar.

"The first cluster of patients was reported at the Huanan Seafood Wholesale Market, and studies have since suggested that the virus could have been introduced there by someone already infected. Wuhan and the surrounding province of Hubei account for the overwhelming amount of cases and deaths, so there is no scientific reason to believe the virus began elsewhere."

Amerika Serika menyebut China harus bertanggung jawab dan tidak bisa menyalahkan negara lain akan terjadinya hal ini karena memang kemunculan wabah ini bermula di kota Wuhan, China.

Diagnose Cause: Peristiwiwa ini disebabkan awalnya bermula dari tuduhan
Amerika Serikat yang mengatakan dan membuat stigma bahwa virus corona berasal dari negara tirai bambu tersebut.

“Mr. Zhao's posts appeared to be a retort to similarly unsubstantiated theories about the origins of the outbreak that have spread in the United States. Senior officials there have called the epidemic the "Wuhan virus," and at least one senator hinted darkly that the epidemic began with the leak of a Chinese biological weapon."

Namun newyorktimes selaku media Amerika Serikat, tidak serta merta menerima tuduhan China, tapi tidak juga membela negaranya, karena disini disebutkan bawasannya baik pihak China dan Amerika saling membuat tuduhan tanpa memiliki bukti valid.

Pihak newyorktimes menyebut, Ketika Amerika menyalahkan China, tu sebagai sebuah pengalihan isu atas gagalnya pemerintah Amerika mengamankan masyarakatnya dari serangan virus ini, namun disisi lain newyorktimes menyebut bahwa China menyalahkan Amerika sebagai sebuah pengalihan perhatian dari kesalahan langkah China ketika virus ini muncul:

"The insinuation came in a series of posts on Twitter by Zhao Lijian, a ministry spokesman who has made good use of the platform, which is blocked in China, to push a newly aggressive, and hawkish, diplomatic strategy. It is most likely 
intended to deflect attention from China's own missteps in the early weeks of the epidemic by sowing confusion or, at least, uncertainty at home and abroad."

Pihak newyorktimes juga menyebut bahwa Presiden China penanganan awal dari kemunculan virus ini, puncaknya ketika kemarahan publik meletus karena tidak adanya peringatan kewaspadaan akan virus mematikan tersebut.

“China's leader, Xi Jinping, has faced sharp criticism for the government's initial handling of the outbreak, even at home. Public anger erupted in February when a doctor who was punished for warning his colleagues about the coronavirus died, prompting censors to redouble their efforts to stifle public criticism."

Make Moral Judgment: Berbagai tuduhan saling dilontarkan oleh kedua negara, bahkan WHO juga sempat melarang untuk mengaitkan virus ini berasal dari wilayah tertentu, alhasil tuduhan tersebut menjadi mentah.

"There is not a shred of evidence to support that, but the notion received an official endorsement from China's Ministry of Foreign Affairs, whose spokesman accused American officials of not coming clean about what they know about the disease."

Dari berbagai statment yang dikeluarkan, tidak ada bukti valid bawasannya virus corona berasal dari salah satu negara yang terlibat blame game, sehingga dirasa ini merupakan sebuah alibi dari masing-masing negara yang gagal dalam menangani virus ini.

\section{Treatment Recommendation:}

Pihak China mendesak agar para pejabat negeri paman sam berhenti menyebut bawasannya virus corona berasal dari negaranya dan tidak mempolitisir ditengah situasi sekarang ini.

"Chinese officials have repeatedly urged officials in other countries not to politicize what is a public health emergency. Conservatives in the United States, in particular, have latched on to loaded terms that have been criticized for stigmatizing the Chinese people."

b. Struktur Framing pemberitaan newyorktimes.com mengenai tingginya tensi hubungan antara Amerika Serikat dan China ditengah Pandemi Virus Corona (From Respect to Sick and Twisted: How Coronavirus Hit U.S.-China Ties)

Define Problems: Peristiwa pandemik virus corona menaikan tensi kedua negara yakni Amerika Serikat dan Republic Rakyat China, hubungan kedua negara meruncing akibat saling tuduh mengenai perdebatan awal mula munculnya virus corona dan juga penanganan virus corona tersebut. 
"A sharp escalation of tensions over the handling of the pandemic has raised the specter of a new Cold War."

NYTimes, media Amerika Serikat, mengatakan adanya hal ini hubungan kedua negara akan membuat perang dingin dengan jenis yang baru.

Diagnose Cause:Masalah ini disebabkan karena adanya pembalasan atas kritik yang dilontarkan Amerika atas penanganan pandemi virus corona oleh China yang dianggap telat.

"Evil." "Lunacy." "Shameless." "Sick and twisted." China has hit back at American criticism over its handling of the coronavirus pandemic with an outpouring of vitriol as acrid as anything seen in decades."

\section{Pihak Amerika Serikat} menganggap, kesalahan China sehingga wabah ini menyebar adalah ketika pejabat China menahan informasi sehingga membuat para dokter tidak memiliki keberanian untuk melaporkan temuan kasus covid19.

"In its first months, the outbreak delivered a political blow to Mr. Xi, after officials held back information and discouraged doctors from reporting cases. Mr. Trump appeared confident that the United States had little to fear, and he praised Mr. Xi's handling of the crisis."

Sempat memiliki kesepakan antara Trum dan Xi untuk bekerjasama untuk memerangi wabah ini secara bersama sama, kesepakatan kembali runtuk ketika trump menganggap China menutupi informasi penting dan membuat akibat jumlah korban wabah ini di Amerika meledak.

"Their brittle unity collapsed as coronavirus deaths exploded in the United States. The White House and the Republican Party tried to shift the focus of ire, blaming China for reacting slowly and covering up crucial information."

Make Moral Judgment: Adanya tuduhan tanpa bikti yang konkrit berakibat rusaknya hubungan bilateral antara Amerika dan China, China menganggap Amerika dan sekutunya ingin menahan kenaikan China sebagai kekuatan Ekonomi.

"The bitter recriminations have plunged relations between China and the United States to a nadir, with warnings in both countries that the bad blood threatens to draw them into a new kind of Cold War. A cycle of statements and actions is solidifying longstanding suspicions in Beijing that the United States and its allies are bent on stifling China's rise as an economic, diplomatic and military power."

Tidak dapat dipungkiri, pada saat ini memang China sebagai salah satu penantang Amerika Serikat dalam urusan ekonomi, Perseteruan Amerika Serikat dan China mengenai pandemi ini meluas ke sektor lainnya. 
"The clash with the United States over the pandemic is fanning broader tensions on trade, technology, espionage and other fronts - disputes that could intensify as President Trump makes his contest with Beijing a theme of his reelection campaign."

Treatment Recommendation: New York Times selaku media Amerika serikat mengkalim melalui berita ini bahwa Donal Trump selaku presiden negara adidaya menelpon presiden China untuk bersama sama mengahadapi wabah ini karena berkaitan dengan darurat kesehatan global.

"Only weeks ago, Mr. Xi and Mr. Trump spoke by telephone and proclaimed their unity in the face of the coronavirus. Mr. Trump declared his "respect" for Mr. Xi, and Mr. Xi told him that countries had to "respond in unison" against a global health emergency."

\section{Pembahasan}

\section{Media Xinhua.com}

Dari penelitian yang diperoleh terdapat dua dimensi dalam pembingkaian analisis framing Robert N. Entman yakni seleksi isu dan penonjolan aspek. Berita mengenai penolakan China terhadap stigma yang diberikan Amerika serikat yang dipublikasikan Xinhua.com kepada khalayak luas karena China sebagai negara tertuduh tidak ingin sepenuhnya disalahkan dalam kasus penyebaran virus covid19 ini yang sudah menyebar ke seluruh dunia. Xinhua.com mengangkat kasus ini karena dalam tuduhan yang diberikan oleh negeri paman sam tidak memiliki bukti yang konkrit dan bisa dipertanggung jawabkan, Donal Trump merupakan tokoh yang gencar menyalahkan China dalam hal ini, presiden ke 45 negara adidaya mengganti sebutan virus corona menjadi virus China.

Dari penyataan kontroversial yang diberikan diberikan Donal Trump, peneliti memilih berita sebagai berikut (1) China opposes U.S. stigmatization by calling coronavirus "Chinese virus"; (2) German agency doubts U.S. coronavirus allegations against Chinese lab; (3) Spotlight: Politicizing coronavirus waste of time in pandemic battle. Peneliti menjadikan berita-berita tersebut kedalam konsep empat berita framing Robert N. Entman. Setelah sudah diketahui empat elemen pada berita tersebut, peneliti menemukan terdapat penonjolan aspek, sehingga peneliti mengetahui pembingkaian media online Xingua.com pada berita kontroversi yang diucapkan oleh Trump mengenai tuduhannya kepada negara yang di pimping Xi Jinping, penekanan Xinhua.com adalah menekankan bawasannya China tidak bisa sepenihnya disalahkan akan adanya penyebaran virus corona yang mengelobal 
ini. Berikut pernyataan penekanan yang diberikan pada media Xinhua.com

"Spokesperson Geng Shuang made the remarks at a press conference when asked to comment on U.S. President Donald Trump's tweet Monday, in which he called the novel coronavirus "Chinese virus, Recently, some U.S. politicians have connected the novel coronavirus with China, aiming to stigmatize China," Geng said. "We are strongly indignant at and firmly oppose that." (China opposes US Stigmatization by calling coronavirus “Chinese Virus")

"The World Health Organization and the international community clearly and definitely opposed to stigmatization by associating the virus with specific countries and regions." (China opposes US Stigmatization by calling coronavirus "Chinese Virus")

"WASHINGTON, (Xinhua) -Germany's federal intelligence agency doubts U.S. allegations that COVID-19 "originated in a Chinese laboratory", saying the allegations were aimed at diverting attention from U.S. failure to contain the disease, U.S. television network CNBC said, citing a German magazine"(German Agency Doubs U.S Coronavirus Allegations Againts Chinese Lab)

"However, instead of focusing efforts on saving lives and livelihoods, politicians in some countries, especially in the United States, have tried to conveniently scapegoat China for their own failures to tackle the coronavirus outbreak." (Spotlight: Politicizing coronavirus waste of time in pandemic battle)

\section{Media New York Times.}

Sedangkan penelitian yang diperoleh dari sumber berita Newyorktimes memiliki pandangan yang berbeda dengan media China, jika dilihat dari dua dimensi dalam pembingkaian analisis framing Robert N. Entman yakni seleksi isu dan penonjolan aspek. Berita mengenai penyataan Trunp yang menyalahkan China dalam penyebaran virus ini, New York Times sebenarnya tidak terlalu pro dalam membela president dari negaranya. Amerika Serikat sebagai sebuah negara adidaya tidak ingin disebut gagal dalam mengatasi wabah ini. Trump dianggap hanya mencari alasan karena dirasa gagal memimpin negaranya dalam mengatasi hal ini sehingga beliau mengkambinghitamkan negara tirai bambu.

Dari pernyataan kontoversiaTrump tidak berhenti menyalahkan China dalam merebaknya virus ini, namun media Amerika Serikat mendukung namun juga tidak sesekali menyalahkan Trump. Dari pernyataan trump tersebut, peneliti memilih berita sebagai berikut: (1) China Spins Tale That the U.S. Army Started the 
Coronavirus Epidemic; (2) rom 'Respect' to

'Sick and Twisted': How Coronavirus Hit U.S.-China Ties; (3) Of Course Trump Deserves Blame For The Corona Virus Crisis. Peneliti menjadikan berita-berita tersebut kedalam konsep empat framing berita Robert N. Entman. Setelah diketahui keempat elemen pada berita tersebut, peneliti menemukan terdapat penonjolan Aspek, sehingga peneliti mengetahui pembigkaian media online NewYorkTimes pada berita mengenai tuduhan Trump kepada China, penekanan NewYorkTimes adalah mungkin China memang salah, namun Trump juga patut disalahkan dengan adanya krisis ini, berikut ernyataan penekanan yang diberikan media Xinhua.com.

"The first cluster of patients was reported at the Huanan Seafood Wholesale Market, and studies have since suggested that the virus could have been introduced there by someone already infected. Wuhan and the surrounding province of Hubei account for the overwhelming amount of cases and deaths, so there is no scientific reason to believe the virus began elsewhere." (China Spins Tale That the U.S. Army Started the Coronavirus Epidemic).

"The insinuation came in a series of posts on Twitter by Zhao Lijian, a ministry spokesman who has made good use of the platform, which is blocked in China, to push a newly aggressive, and hawkish, diplomatic strategy. It is most likely intended to deflect attention from China's own missteps in the early weeks of the epidemic by sowing confusion or, at least, uncertainty at home and abroad." (China Spins Tale That the U.S. Army Started the Coronavirus Epidemic).

"In its first months, the outbreak delivered a political blow to $\mathrm{Mr}$. Xi, after officials held back information and discouraged doctors from reporting cases. Mr. Trump appeared confident that the United States had little to fear, and he praised Mr. Xi's handling of the crisis."

"Their brittle unity collapsed as coronavirus deaths exploded in the United States. The White House and the Republican Party tried to shift the focus of ire, blaming China for reacting slowly and covering up crucial information." (From Respect to Sick and Twisted: How Coronavirus Hit U.S.-China Ties)

\section{DAFTAR PUSTAKA}

\section{Buku}

Baym, N. K. (2002). Interpersonal Life Online; dalam Lievrouw, L. A. and Livingstone, S. (ed.), The Handbook of New Media , hlm. 62-76. London: Sage

Eriyanto. 2011. Analisis Isi: Pengantar Metodologi untuk Penelitian 
Ilmu Komunikasi dan Ilmu-ilmu Sosial Lainnya. Jakarta: Kencana.

McQuail, D. (2011). McQuail Mass

Communication Theory. Singapore: Sage

Thurlow, C. , et al. (2005). Computer Mediated Communication. London: Sage Publication.

Berger, Thomas.L, Peter, Luckman. (1996). The Social Construction of Reality: A Treatise in the Sociology of Knowledge: United States: Anchor Books.

Vera, Nawiroh. 2008. Pengantar Komunikasi Massa. Jakarta: Renata Pratama Media.

\section{Internet}

(https://economy.okezone.com/re ad/2016/03/16/320/1337230/96-

masyarakat-indonesia-konsumsi-beritaonline diakses 19/03/ 2020,20:42 WIB).

(https://www.kompas.com/tren/r ead/2020/02/01/083000465/6-hal-yangperlu-diketahui-soal-virus-corona-apasaja-diakses 20/03/ 2020, 10:29 WIB).

(https://bali.idntimes.com/health/ medical/denny-adhietya/asal-muasal-danperjalanan-virus-corona-dari-wuhan-keseluruh-dunia-regional-bali/full diakses 20/03/2020, 21:50 WIB) (https://style.tribunnews.com/am p/2020/04/21/update-corona-dunia-21april-2020-kematian-di-as-tembus-40ribu-jerman-terbanyak-pasiensembuh?page=2 Diakses 21 April 2020 pukul 19:50). 